\title{
Import Substitution in High-Tech Industries of the Agro-Industrial Complex in Russia
}

\author{
VERONIKA YU. CHERNOVA \\ Department of Marketing, \\ Peoples' Friendship University of Russia \\ 6 Miklukho-Maklaya Str., Moscow, 117198; \\ Institute of Marketing, \\ State University of Management. \\ 99, Ryazanskiy prospect st., Moscow, 109542 \\ RUSSIAN FEDERATION \\ BORIS A. KHEYFETS \\ Institute of Economics of the Russian Academy of Sciences \\ 32 Nakhimovsky Prospect, Moscow, 117218; \\ Financial University under the Government of the Russian Federation \\ 49 Leningradsky Prospect, Moscow, 125993 \\ RUSSIAN FEDERATION
}

\begin{abstract}
The paper examines the prospects for import substitution in high-tech industries of Russia's agroindustrial complex (AIC). It aims to identify and assess the factors behind the priority of import substitution policy. The research employs the methods of economic-statistical and correlation analysis. The results show that there are four types of government support that exert the most profound effect on import substitution in mechanical engineering and the AIC sectors based on high technologies and innovations. These are compensation for direct costs incurred in the construction and modernization of the AIC facilities; investment lending in the AIC; soft loans for the AIC enterprises; and the creation of the Center for the Analysis of Agricultural Products Export (Prod.Center). The study highlights the major challenges and avenues for import substitution in the Russian agroindustrial complex. The results obtained can be used when formulating a development strategy for high-tech agricultural sub-sectors and forming industry-specific and regional development programs.
\end{abstract}

Key-Words: - import substitution, high-tech production, agriculture, government support, domestic market. [

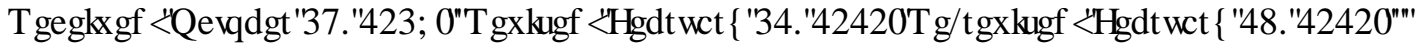

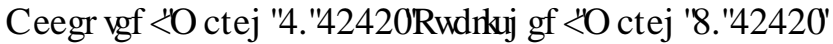

\section{Introduction}

Currently, the Russian economy exhibits significant disproportions in the industrial structure. A negative balance of trade and relying on imports to satisfy final and intermediate needs indicate the necessity to introduce import substitution policy in Russia and stimulate the development of high-tech industries [1].

Demonstrating a vast intellectual, technological and human potential, Russia has encountered a serious socioeconomic crisis. Deindustrialization is the most dangerous threat. All this damages the country's industrial capacity [2], since the application of innovative technologies serves as the basis for economic reproduction [3]. In this context, import substitution in Russia is a factor in achieving sustainable economic growth. These trends are evident in the agro-industrial complex (AIC) and agriculture.

In this respect, searching for new ways to meet the needs for imports and to create import substitution production with a higher turnover rate is becoming increasingly relevant. Since import substitution production should actually be started from scratch, comprehensive government support for the AIC enterprises, ensuring a stable business environment and creating the most favorable investment conditions are of considerable importance [4]. In view of this, the Strategy for the Development of Agricultural Machinery and the Strategy for the Development of 
Food and Processing Machinery were designed and approved. These documents stipulated the course on modernization through the introduction of high-tech machinery. However, an obsolete interpretation of the essence and the structure of the agro-industrial complex remains an obstacle on the way to the renewal of its production assets [5].

The solution to this problem requires the structure of the AIC and agriculture to be comprehensively analyzed, and the directions and effectiveness of the import substitution policy to be established. Consequently, the purpose of the study is to evaluate the opportunities for import substitution in the AIC through the introduction of high-tech machinery. To fulfil the stated purpose, we aim to accomplish the following objectives: to identify the factors in the development of agricultural engineering; to establish the relationships between these factors; and to substantiate the avenues for the import substitution policy in the agro-industrial complex.

\section{Literature Review}

Economic prospects are traditionally associated with the growth in the domestic market, which can be realized, among other things, through the development of import-substituting products $[6 ; 7,8]$. However, the loss of competitive positions might impede the use of this import substitution model in Russia. We suppose that import substitution industrialization based on active introduction of innovations and technologies and renewal of fixed assets is an alternative approach to import substitution [9].

The literature review shows that import substitution policy is often associated with structural reforms (for example, in Latin America [10; 11; 12] or Southeast Asia $[13 ; 14 ; 15])$. The special features of the implementation of this strategy through the prism of attracting foreign direct investment are discussed in [16; 17]. Some distinctive aspects of import substitution in Russia are investigated in $[7 ; 18 ; 19]$. Despite the fact that the aforementioned issues are widely debated in scientific publications, the role and influence of government support still remains unclear.

The importance of state regulation and participation in the AIC is due to a number of reasons. Here, it is of primary importance to ensure the adequate level of food security in the country and enhance its export potential [20; 21; 22; 23]. Government support for the AIC can contribute to scientific and technological progress and accelerate the transition to an innovative development model of agricultural enterprises. Since the influence of technological factors on the structural processes in the AIC is growing every year, they predetermine the need for the development of both its resource base and change in the role of individual participants in the chain of creation and processing of agricultural products. All this makes the research studies on the development prospects of the AIC more relevant.

The works exploring the dynamics of agricultural production trends by various factors are of significant interest. According to recent research on agriculture in Russia, a decline in agricultural production growth is expected and a decrease in imports is attributed to limited consumer and investment demand, to the introduction of additional import duties and low gray imports due to a fall in the purchasing power of the population [24]. Against a backdrop of stabilization of some domestically oriented industries, we agree that import substitution products should be manufactured in parallel with the development of export-oriented industries, which produces long-term and short-term effects [25].

To sum up, import substitution industries of the AIC are able to transform themselves into exportoriented ones under a number of conditions. At that, the development of high-tech industries is a decisive factor in the implementation of the import substitution industrialization model [26] which will largely determine import substitution in the agro-industrial complex.

\section{Method}

The achieved level of production capacity utilization is used as the main parameter for choosing the avenues for import substitution. It shows the amount of reserves for intensifying agricultural activity and a simultaneous rise in the number of opportunities to meet the needs for commodity nomenclatures. The factor characteristics include various avenues for government support aimed at modernizing and reconstructing the AIC facilities:

Pok $_{1}$ is compensation for direct costs incurred in the construction and modernization of the AIC facilities;

$\mathrm{Pok}_{2}$ is the support for investment lending in the AIC;

$\mathrm{Pok}_{3}$ is soft loans for the AIC enterprises; 
$\mathrm{Pok}_{4}$ is level of assistance to the Federal Service for Veterinary and Phytosanitary Surveillance (Rosselkhoznadzor);

$\mathrm{Pok}_{5}$ is the creation of the Center for the Analysis of Agricultural Products Export (Prod.Center);

$\mathrm{Pok}_{6}$ is improvement of agricultural land.

The study is based on correlation analysis. In the course of the assessment we calculated Pearson's correlation coefficient.

The integral index of the level of production capacity utilization $i_{L P C U}$ is calculated by formula:

$$
i_{L P C U}=\frac{\sum_{i=1}^{n} P o k_{1}}{n},
$$

where $P o k_{i}$ is value of the $i$-th indicator; $\mathrm{n}$ is the number of indicators.

To study the distinguishing features of the AIC development retrospectively, it is expedient to apply the theory of technological paradigms that combines Kondratiev's long waves with a periodic renewal of the technological structure of production. The technological specificity of agriculture based on the laws of nature lies in invariable principles for the application of the basic technologies utilized to manufacture products. At the same time, the overall scientific and technological progress has a more profound effect on resource-supplying and processing industries which, due to the evolution of technological structures, unlock new economic potential. This explains a discrepancy in the changes in technological paradigms in agriculture and other industries.

In practice, there is no clear temporal and structural distinction between technological paradigms in agriculture. The multistructure of agriculture is confirmed by its corporate and individual sectors that have different access to technological resources and opportunities for using them.

A study of the technological paradigms of agricultural production has revealed the following relationships between technological and organizational development factors [27]:

- the natural paradigm (similar to the preindustrial one) is characteristic of private households and farms that use mostly manual labor and basic agricultural machinery and employ traditional technologies for crop cultivation; the sector focuses on manufacturing organic products;

- the natural-innovative paradigm (similar to the industrial one) is typical of collective households and farms that rely mostly on mechanical production, use modern agricultural machinery and introduce advanced agricultural technologies; the segment also focuses on manufacturing organic products;

- the intensive-technocratic paradigm (similar to the industrial-informational one) is characteristic of agricultural holdings and large enterprises that use state-of-the-art agricultural machinery minimizing manual labor and introduce high information technologies.

The information base of the study includes the statistical data provided by the Ministry of Agriculture of the Russian Federation, the National Report on the implementation of the State Program for Agricultural Development and Regulation of Agricultural Products, Commodities and Food Markets; the data of the Federal State Statistic Service (Rosstat).

\section{Results}

\subsection{Analysis of Russia's Agricultural Sector}

In our view, the opportunities for Russia's economic growth are closely related to the realization of the AIC potential. It is expedient to establish the prospects proceeding from the changes in the technological provision of the AIC. It is worth mentioning that there are diverse interpretations of the role of agriculture in the resource supply of economy [28]. At the same time, many researchers note that the development of the AIC should correspond to the criteria for reducing specific transaction and logistics costs [29]. Special attention, therefore, is paid to vertically integrated structures [30].

According to the concept of integration, it seems reasonable to hypothesize that the development of the agro-industrial complex should be carried out on fundamentally different grounds, which require a paradigm shift in the relationships between agriculture and its supporting industries.

The hypothesis is valid due to the fact that the AIC high-tech industries (mechanical engineering, chemical industry, etc.) serve the low-tech industry, i.e. agriculture, which is unprofitable and inefficient. This results in low efficiency of the entire agroindustrial complex (Fig. 1). 


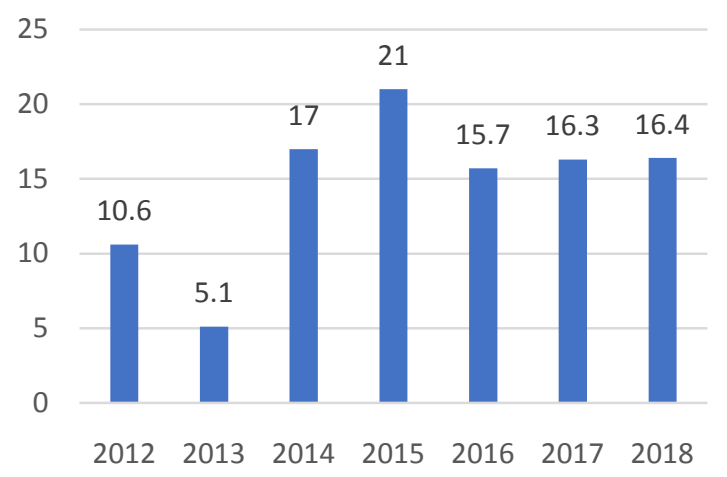

As seen from Fig. 1, return on sales in the Russian agricultural sector declined after 2015. At that, the indicator demonstrates lower values if compared with developed countries. We suppose that the technological factor plays a significant part here. For example, agricultural enterprises display low innovation activity (Fig. 2).

Fig.1. Return on sales in the agricultural sector of Russia, \% Source: [31].

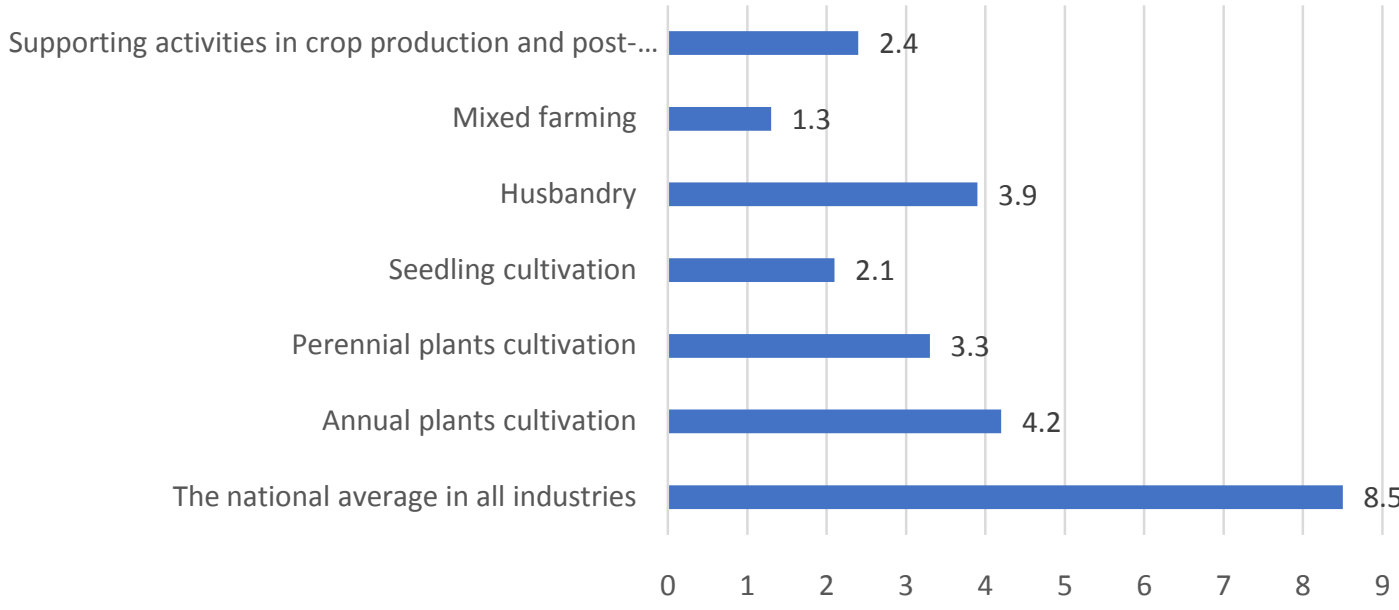

Fig.2. Innovation activity of Russia’s agricultural enterprises by types of activities, \% Source: [31].

Fig. 2 shows that the innovation activity of Russia's agricultural enterprises is more than two times lower than the national average in all industries.
The indicators of acquiring new technologies are low as well (Table 1).

Table 1. Amount of new technologies (technical achievements) and software products acquired

\begin{tabular}{|l|l|l|l|l|l|l|}
\hline \multirow{2}{*}{ Activity of the AIC } & \multicolumn{2}{c|}{2017} & \multicolumn{2}{c|}{2018} & \multicolumn{2}{c|}{$2018 / 2017$} \\
\cline { 2 - 8 } & \multicolumn{1}{|c|}{ Units } & \multicolumn{2}{c|}{$\%$} & Units & \multicolumn{1}{c|}{ Units } & $\%$ \\
\hline Annual plants cultivation & 635 & 3.2 & 242 & 1.1 & -393 & -2.1 \\
\hline Husbandry & 526 & 2.6 & 188 & 0.8 & -338 & -1.8 \\
\hline Mixed farming & 0 & 0.0 & 1 & 0.0 & 1 & 0.0 \\
\hline $\begin{array}{l}\text { Supporting activities in crop production and post- } \\
\text { harvest processing of agricultural products }\end{array}$ & 15 & 0.1 & 33 & 0.1 & 18 & 0.1 \\
\hline Total & 20042 & 100 & 22678 & 100 & 2636 & 0.0 \\
\hline
\end{tabular}

Source: [31].

An analysis of the data from Table 2 allows us to conclude that the AIC enterprises are not active in using modern technologies: the amount of technologies acquired is quite limited and it decreased in 2018 even more in comparison with 2017. 


\subsection{Evaluating the Opportunities for Import Substitution in the Russian Agro-Industrial Complex}

The development of large enterprises increases the technological level of agricultural production [27]. This, in turn, results in the growth of agricultural production and the formation of its supply in the market. Economically, further introduction of new technologies aimed at enhancing the production of agricultural products for the food market is limited. This technological link is due to the correspondence between the uniformity of technological development (application of technologies) of all industries engaged in the production of high-tech products, whereas the high expenses on technologies in agriculture are offset by the distribution of technological rents among the participants in the technological chain, including agricultural enterprises. Thus, the lack of integration of agricultural production with high-tech enterprises in the sphere of designing high-tech products causes a certain imbalance.

It is possible to eliminate this imbalance through comprehensive government support, which determines the necessity to evaluate the effectiveness of the measures taken. To do so, we have applied the abovementioned approach based on calculation of the integral index. As a result, we have obtained factor characteristics influencing mechanical engineering in the context of implementation of the import substitution policy in the AIC (Table 2).

Table 2. Assessment of factor impact on the development of mechanical engineering in the context of implementation of the import substitution policy in the AIC

\begin{tabular}{|c|c|c|c|c|c|c|c|}
\hline \multirow{2}{*}{ Industry of the AIC } & \multirow{2}{*}{ Index } & \multicolumn{6}{|c|}{ Factor characteristics } \\
\hline & & Pok $_{1}$ & $\mathrm{Pok}_{2}$ & $\mathrm{Pok}_{3}$ & $\mathrm{Pok}_{4}$ & Pok $_{5}$ & $\mathrm{Pok}_{6}$ \\
\hline \multirow{2}{*}{ Pig breeding } & $r_{i}$ & 2.374 & 2.527 & 1.444 & 2.278 & 2.168 & 1.840 \\
\hline & $i_{L P C U}$ & 0.791 & 0.842 & 0.481 & 0.759 & 0.723 & 0.613 \\
\hline \multirow{2}{*}{ Poultry farming } & $r_{i}$ & 2.649 & 2.511 & 1.687 & 2.499 & 2.548 & 1.645 \\
\hline & $i_{L P C U}$ & 0.883 & 0.837 & 0.562 & 0.833 & 0.849 & 0.548 \\
\hline \multirow{2}{*}{ Cattle production } & $r_{i}$ & 1.739 & 1.511 & 1.763 & 1.600 & 1.842 & 0.992 \\
\hline & $i_{L P C U}$ & 0.580 & 0.504 & 0.588 & 0.533 & 0.614 & 0.331 \\
\hline \multirow{2}{*}{ Milk production } & $r_{i}$ & 0.870 & 0.532 & 1.885 & 0.811 & 1.158 & 1.348 \\
\hline & $i_{L P C U}$ & 0.290 & 0.177 & 0.628 & 0.270 & 0.386 & 0.449 \\
\hline \multirow{2}{*}{ Crop farming } & $r_{i}$ & 2.627 & 2.564 & 1.894 & 2.653 & 2.669 & 1.155 \\
\hline & $i_{L P C U}$ & 0.876 & 0.855 & 0.631 & 0.884 & 0.890 & 0.385 \\
\hline
\end{tabular}

Source: the calculation is based on the data of the Ministry of Agriculture of the Russian Federation (2017) [32] and the National Report (2019) [33].

The research showed that these were the following types of government support that exerted the greatest impact on the implementation of import substitution in mechanical engineering and the AIC industries using high technologies and innovations: compensation for direct costs incurred in the construction and modernization of the AIC facilities; investment lending in the AIC; soft loans for the AIC enterprises; and the creation of the Center for the Analysis of Agricultural Products Export (Prod.Center).

\section{Discussion}

The research results demonstrate that the technological development of the Russian agroindustrial complex is not intensive enough. The indicators of innovation activities of agricultural enterprises are significantly lower than in other Russian industries and agribusiness in developed countries. In this context, it is of high importance to improve the effectiveness of government support for these processes.

Overcoming the economic crisis in the agricultural sector requires the formation of a rational structure of production potential and the creation of favorable conditions to use it. The solution to this multi-faceted problem should be comprehensive, i.e. embrace all 
types of resources, industries and the AIC production. The role of the state is to provide organizational and administrative assistance to business, create market infrastructure and stimulate export. Table 3 presents the fundamental import substitution principles exercised in other countries.

Table 3. Fundamental import substitution principles

\begin{tabular}{|l|l|}
\hline \multicolumn{1}{|c|}{ Principle } & \multicolumn{1}{c|}{ Measures } \\
\hline $\begin{array}{l}\text { Import substitution should be a transitional stage in the } \\
\text { process of economic restructuring. It should be used for } \\
\text { accelerated modernization and development of new } \\
\text { industrial areas followed by a consistent transition to an } \\
\text { export-oriented development model }\end{array}$ & $\begin{array}{l}\text { Government support for exports; } \\
\text { search for promising trading and investment partners; } \\
\text { information and advisory services; } \\
\text { government lending and insurance of export operations; } \\
\text { marketing support; } \\
\text { improving the country's image for more successful } \\
\text { promotion of its goods to foreign markets }\end{array}$ \\
\hline $\begin{array}{l}\text { Import substitution is carried out in several important } \\
\text { industries }\end{array}$ & $\begin{array}{l}\text { Choosing the industries with a certain level of technological } \\
\text { development and a sufficiently developed infrastructure }\end{array}$ \\
\hline $\begin{array}{l}\text { Ensuring the growth of labor productivity and } \\
\text { competitiveness }\end{array}$ & $\begin{array}{l}\text { Introduction of production, organizational and other types } \\
\text { of innovation; } \\
\text { increasing the volume of new products based on domestic } \\
\text { scientific-technical and industrial-technological potential } \\
\text { and through the acquisition of licenses for foreign high } \\
\text { technologies }\end{array}$ \\
\hline $\begin{array}{l}\text { Stimulating technological imports and innovation } \\
\text { management }\end{array}$ & $\begin{array}{l}\text { Attracting foreign investments in the form of new } \\
\text { technologies; } \\
\text { localization of production capacities of multinationals }\end{array}$ \\
\hline
\end{tabular}

As for the proposed methodological approach to assessing influence, we agree that these calculations do not cover the issues of the country's resource capabilities in the production of certain types of products. Moreover, such a factor as technological capabilities for the production of competitive products that could serve as a substitute for externally produced goods was not taken into account. For this purpose, to provide an in-depth review of each of the studied types of activities, a generalized analysis was carried out and the main problems of these processes were identified (Table 4).

Table 4. Problems and avenues for import substitution in the Russian agro-industrial complex

\begin{tabular}{|c|c|c|c|}
\hline $\begin{array}{c}\text { Problems of the industry } \\
\text { development }\end{array}$ & $\begin{array}{c}\text { Many enterprises lack direct } \\
\text { relationships with commodity } \\
\text { suppliers and access to markets; } \\
\text { high energy intensity of } \\
\text { production; ultra-high wear and } \\
\text { tear of fixed assets; holes in } \\
\text { legal support, which creates } \\
\text { unequal conditions for Russian } \\
\text { and foreign manufacturers }\end{array}$ & $\begin{array}{c}\text { Dependence on imports of commodities and intermediate } \\
\text { consumption materials. Wear and tear of fixed assets at most } \\
\text { enterprises. Low staffing level }\end{array}$ & $\begin{array}{c}\text { The need to compete with } \\
\text { multinationals in Russia's } \\
\text { food market } \\
\text { production. Wear and tear of } \\
\text { fixed assets at the } \\
\text { overwhelming majority of } \\
\text { enterprises }\end{array}$ \\
\hline $\begin{array}{c}\text { Avenues for import } \\
\text { substitution }\end{array}$ & $\begin{array}{c}\text { Sub-industries possessing a high } \\
\text { potential for production of } \\
\text { innovative products of deep } \\
\text { processing, commodity and } \\
\text { technological base for its } \\
\text { production, as well as a high } \\
\text { export potential }\end{array}$ & $\begin{array}{c}\text { Poultry and crop farming } \\
\text { (considering that most } \\
\text { enterprises in this industry } \\
\text { currently use imported } \\
\text { machinery and equipment) }\end{array}$ & $\begin{array}{c}\text { Products of deep processing } \\
\text { oriented towards end } \\
\text { consumers }\end{array}$ \\
& & & \\
\end{tabular}

The foregoing shows that further scientific studies should be concentrated on formulating a strategy for the AIC development based on technological advances. 


\section{Conclusion}

Russia is gradually running out of the opportunities for inertial growth stimulated by traditional factors (in particular, favorable global market conditions for key commodity export positions). Under such conditions, the major economic revival tool is import substitution based on the implementation of regulatory mechanisms that would restrain growing import and optimize its structure.

The paper proposes the measures to improve the effectiveness of government policy and the rationale behind national industry priorities. Modernization and technological renewal of mechanical engineering in Russia is one of the main organizational-economic measures. Based on statistical and correlation analysis of government support for the agro-industrial complex, the article assesses the priority industries for import substitution.

\section{Acknowledgments:}

This article was prepared with the financial support of the Russian Foundation for Basic Research (RFBR), the project "Enhancing Military-Economic Cooperation in the Space of the Collective Security Treaty Organization and the Eurasian Economic Union in the Context of the Sanctions Policy of Developed Countries and the Development of Import Substitution in the Russian Federation", No. 18-01001132.

\section{References}

[1] Romanova, O.A., Korovin, G.B., Kuzmin, E.A. Analysis of the Development Prospects for the High-Tech Sector of the Economy in the Context of New Industrialization, Espacios, No. 38(59), 2017, Art. No. 25.

[2] Bukhvald, E.M. (ed.). Priorities of Modernization and Strengthening the Role of Sub-Federal Management, Moscow, Institute of Economics of the RAS, 2015.

[3] Chernova, V.Yu. Russian Consumer in the Digital Economy, Discussion, Vol. 2, No. 93, 2019, pp. 38-42.

[4] Reymer, V.V., Ulezko, A.V., Tyutyunikov, A.A. Innovation-oriented development of the AIC of the Far East, Voronehz, Voronehz State Agrarian University Publ., 2016.

[5] Bogachev, A.I. Innovation Activity in Agriculture of Russia: Current Trends and
Challenges, Bulletin NGIEI, Vol. 5, No. 96, 2019, pp. 95-106.

[6] Kornilova, L.M., Ivanova, E.A., Ivanov, P.A. Stimulating the Innovative Activity of Agricultural Organizations as the Basis of Digitalization of the AIC, Innovative Development of Economy, Vol. 5, No. 47, 2018, pp. 52-58.

[7] Kuzminov, I.F., Bakhtin, P.D., Khabirova, E.E. World Agriculture "Turns Green": A Reflection of the Trend in the Scientific and Industrial Periodicals, Moscow, HSE Publishing House.

[8] Chernova, V.Y., Zobov, A.M., Starostin, V.S., Butkovskaya, G.V. 2017. Sustainable Marketing Communication Strategies of Russian Companies under the Import Substitution Policy, Entrepreneurship and Sustainability Issues, Vol. 5, No. 2, pp. 223-230. http://doi.org/10.9770/jesi.2017.5.2(5)

[9] Batkovskiy, A.M., Kalachikhin, P.A., Semenova, E.G., Telnov, Y.F., Fomina, A.V. (2016). Economic-Mathematical Model and Mathematical Methods for Substantiating the Choice of the Company Innovation Strategy. Indian Journal of Science and Technology, Vol. 9, No. 27, 2016. https://doi.org/10.17485/ijst/2016/v9i27/97662

[10] Prebisch, R. Peripheral Capitalism: Is There an Alternative? Moscow, Latin America Institute of the RAS, 1992.

[11] Furdato, C. Economic Development of Latin America: Historical Background and Contemporary Problems. Cambridge Latin American Studies, 1977. https://doi.org/10.1017/CBO9780511549939

[12] Bielschowsky, R. Celso Furtado's Contributions to Structuralism and Their Relevance Today, CEPAL Review, No. 88, 2006, pp. 7-14. https://doi.org/10.18356/4267836e-en

[13] Burton, H. A Reconsideration of Import Substitution. Journal of Economic Literature, Vol. 36, No. 2, 1998, pp. 903-936.

[14] Dargin, J. Promoting Industrialization: Trade and Industrialization Strategies for the Global South. Working Paper, 2011.

[15] Zhang, L. Innovations in Agricultural Science and Technology and Rural Development in 
China. The Chinese Academy of Agricultural Sciences, CAAS, 2015.

[16] Balasubramanyam, V., Salisu, M., Sapsford, D. Foreign Direct Investment and Growth in EP and IS Countries. The Economic Journal, Vol. 106, 1996, pp. 92-105. https://doi.org/10.2307/2234933

[17] Olofsdotter, K. (1998). Foreign Direct Investment, Country Capabilities and Economic Growth. Weltwirtschaftliches Archiv, Vol. 134, No. 3, 5p. 534-547. https://doi.org/10.1007/BF02707929

[18] Dynkin, A.A., Ivanova, N.I. (eds.). Innovation Economics. Moscow, Nauka Publ., 2004.

[19] Glaziev, S.Yu. Applied Results in the Theory of World Economic Structures, Economics and Mathematical Methods, No. 3, 2016, pp. 3-21.

[20] Kuzmin, E.A. Theoretical and Empiric Studies of Economic Security in Liberalized Trade Relations. Part 1. Theoretical and Methodological Positioning of a Problem and Possible Solutions, National Security/Nota Bene, No. 1, 2013, pp. 34-50. https://doi.org/10.7256/2073-8560.2013.01.5

[21] Kuzmin, E.A. The Issue of Isolated Economic Security in Free Trade: A Look at the Interaction of Russia and the WTO, Bulletin of SRSPU (NPI). Series: Socio-Economic Sciences, No. 6, 2012, pp. 44-59.

[22] Nagyová, L., Holiencinová, M., Rovnỳ, P., Dobák, D., Bilan, Y. Food Security Drivers: Economic Sustainability of Primary Agricultural Production in the Slovak Republic. Journal of Security and Sustainability Issues, Vol. 6, No. 2, 2016, pp.

259-274. https://doi.org/10.9770/jssi.2016.6.2(6)

[23] Faridi, M.F., Sulphey, M.M. Food Security as a Prelude to Sustainability: A Case Study in the Agricultural Sector, Its Impacts on the Al Kharj Community in The Kingdom of Saudi Arabia, Entrepreneurship and Sustainability Issues, Vol. 6, No. 3, 2019, pp. 1336-1345. https://doi.org/10.9770/jssi.2019.6.3(34)

[24] Sagidov, Yu.N. Activation of Development of Agrarian-Oriented Regions of Russia, Regional Problems of Transforming the Economy, Vol. 9, No. 71, 2016, pp. 102-111.
[25] Arezki, R., Hadri, K., Rao, Y., Loungani, P. Testing the Prebisch-Singer Hypothesis since 1650: Evidence from Panel Techniques that Allow for Multiple Breaks, IMF, 2013. https://doi.org/10.5089/9781484341155.001

[26] Makedon, V., Drobyazko, S., Shevtsova, H., Maslosh, O., Kasatkina, M. Providing Security for the Development of High-Technology Organizations. Journal of Security and Sustainability Issues, Vol. 8, No. 4, 2019, pp. 759-774. https://doi.org/10.9770/jssi.2019.8.4(18)

[27] Kapur, R. Usage of Technology in the Agricultural Sector. Acta Scientific Agriculture, Vol. 2, No. 6, 2018, pp. 78-84.

[28] Rivza, B., Kruzmetra, M. Through Economic Growth to the Viability of Rural Space, Entrepreneurship and Sustainability Issues, Vol. 5, No. 2, 2017, pp. 283-296. http://doi.org/10.9770/jesi.2017.5.2(9)

[29] Popova, I.N., Vlasov, A.I., Nikitina, N.I. Optimization of Inventory Distribution Logistics in Industrial Enterprises. Espacios, Vol. 39, No. 24, 2018, Art. No. 16.

[30] Fomina, A.V, Berduygina, O.N., Shatsky, A.A. Industrial Cooperation and Its Influence on Sustainable Economic Growth. Entrepreneurship and Sustainability Issues, Vol. 5, No. 3, 2018, pp. 467-479. https://doi.org/10.9770/jesi.2018.5.3(4)

[31] Federal State Statistics Service (Rosstat). Official statistical data 2019. http://www.gks.ru/

[32] Forecast of the Scientific and Technological Development of the Agro-Industrial Complex of the Russian Federation for the Period until 2030. The Ministry of Agriculture of the Russian Federation; National Research University Higher School of Economics. Moscow, HSE Publishing House, 2017.

[33] National Report of the RF Government 2019. National Report on the progress and results of the implementation in 2018 of the State Program for Agricultural Development and Regulation of Agricultural Products, Commodities and Food Markets.

fhttp://mcx.ru/upload/iblock/61d/61d430039b886 3186a4fbb1f60fab1c6.pdf 